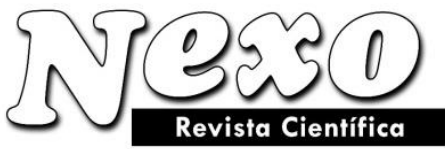

Vol. 34, No. 01, pp. 356-362/Marzo 2021

\title{
Key vectors of personnel marketing development: finding a balance between marketing and HR management from the perspective of cognitive modeling
}

\section{Vectores clave del desarrollo del marketing de personal: encontrando un equilibrio entre el marketing y la gestión de RRHH desde la perspectiva del modelado cognitivo}

\author{
A.V. Nikitina*, L.N. Zaharova, B.B. Lobanova, G.G. Vukovich \\ Kuban State University, Krasnodar, Russia. \\ "nikitina.an.v@bk.ru
}

(recibido/received: 21-October-2020; aceptado/accepted: 17-December-2020)

\begin{abstract}
Human resources management remains an important area of modern enterprise strategy, as the role of personnel increases in high-tech production, and the highest requirements are placed on competencies. The goal of personnel-marketing is to influence the choice of profession and place of work. Labor carrierthe buyer evaluates and makes a decision about choosing a workplace depending on how much the workplace actualizes his ability to work and meets his expectations as an employee. Discussion. Note that the choice of a job occurs twice: when the candidate sends a resume to the company and when the candidate makes a decision after the interview. The development prospects of any enterprise are closely linked to existing market trends, knowledge of which helps to choose the appropriate strategy and directions for the development of competencies and the distribution of labor resources. Results. These circumstances actualize the study of the concept of personnel marketing, which is especially important in the context of increasing market uncertainty (sanctions, sanitary and epidemiological restrictions, etc.).
\end{abstract}

Keywords: relationship marketing, personnel management, internal labor market, HR-technologies, corporate strategy.

\section{RESUMEN}

La gestión de recursos humanos sigue siendo un área importante de la estrategia empresarial moderna, a medida que aumenta el papel del personal en la producción de alta tecnología y se imponen los requisitos más altos a las competencias. El objetivo del marketing de personal es influir en la elección de la profesión y el lugar de trabajo. Transportista de mano de obra: el comprador evalúa y toma una decisión sobre la elección de un lugar de trabajo en función de cuánto el lugar de trabajo actualiza su capacidad para trabajar y cumple con sus expectativas como empleado. Discusión. Tenga en cuenta que la elección de un trabajo se produce dos veces: cuando el candidato envía un currículum a la empresa y cuando el candidato toma una decisión después de la entrevista. Las perspectivas de desarrollo de cualquier empresa están estrechamente vinculadas a las tendencias del mercado existente, cuyo conocimiento ayuda a elegir la estrategia y las orientaciones adecuadas para el desarrollo de competencias y la distribución de los recursos laborales. Resultados. Estas circunstancias actualizan el estudio del concepto de marketing de 
personal, que es especialmente importante en un contexto de creciente incertidumbre del mercado (sanciones, restricciones sanitarias y epidemiológicas, etc.).

Palabras clave: marketing relacional, gestión de personal, mercado laboral interno, tecnologías de recursos humanos, estrategia corporativa.

\section{INTRODUCTION}

As an interdisciplinary field in modern innovative marketing, a cognitive personnel marketing is developed at the intersection of personnel marketing and cognitive psychology. Modernization of modern HR marketing is possible through its interdisciplinary interaction with economic sociology, economic psychology, cognitive psychology, logistics and enterprise Economics. Interdisciplinary research expands the problem field of personnel marketing and allows us to reflect the holistic and systemic relationships that exist between participants in the internal labor market. Today, the development of the theory and practice of cognitive personnel marketing in both theoretical and practical aspects is at an early stage. The key task of personnel marketing is to analyze and control the situation on the labor market in order to effectively cover the need for personnel and implement organizational, technological, financial, economic, and social and labor goals of the enterprise. The study of personnel marketing based on cognitive modeling is of particular interest to the business community, because there is no unified system of cognitive knowledge about how thinking works and what laws govern the perception and attention of personnel. The purpose of this research is to consider cognitive modeling and determine the possibilities of its use in the concept of personnel marketing as a tool for creating competitive advantages of enterprises, as well as modeling the behavior of HR managers in the context of modern socio-economic challenges.

\section{METHODS}

In personnel marketing, methods are used that are a synthesis of marketing and personnel management methods. The main difference between personnel marketing and classical methods of personnel management is that personnel marketing consider the labor market as a sphere that operates according to market laws, which allows personnel marketing to increase the competitiveness of the enterprise. Today, the entrepreneurial-market approach prevails in working with personnel, in which labor, its conditions and jobs are considered as marketing products. In our opinion, it is legitimate to talk about two main principles of personnel marketing. The first involves considering the tasks of personnel marketing in a broad sense. In this case, a personnel marketing refers to a certain philosophy and strategy of human resource management. Personnel are considered as external and internal clients of the company. The second principle assumes the interpretation of personnel marketing in a narrow sense as a function of the personnel management service, which includes: monitoring external and internal factors that determine the direction of marketing activities and the implementation of the personnel marketing program.

The difference between the principles is that a broad interpretation of personnel marketing implies its attribution to one of the elements of the personnel policy of the enterprise, implemented through the solution of the tasks of the personnel management service. In a narrow sense, a personnel marketing involves the allocation of special activities of the personnel management service related to its information function.

Recruitment, selection, and hiring of company personnel require the use of innovative methods of personnel marketing. We will present an overview of traditional approaches to HR marketing in the form of a cognitive graph, highlighting the marketing approach (Figure 1). 

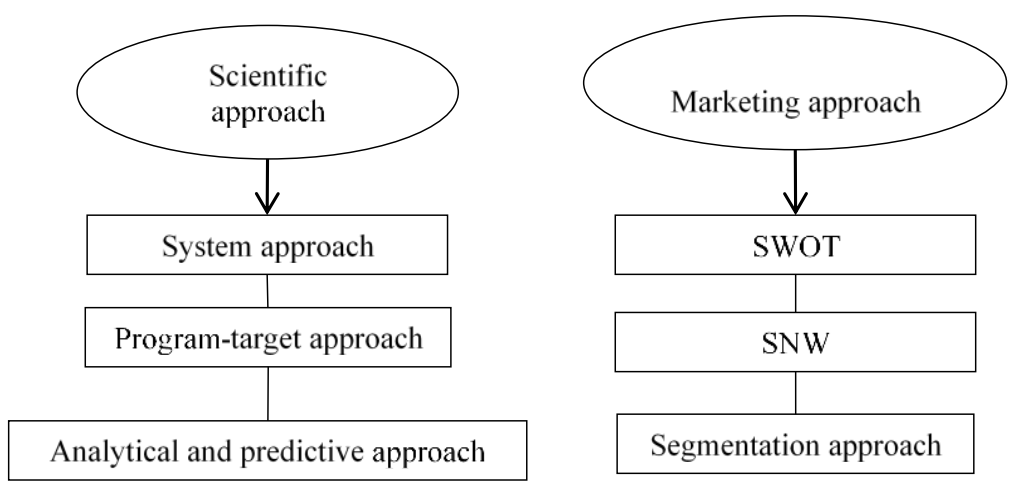

Figure 1. Personnel marketing approaches

The HR marketing approaches presented by us are characterized by special application boundaries, advantages and disadvantages. Scientific approaches allow us to consider the market situation as an object of study that has a wide range of internal and external factors. Information obtained by enterprises using a systematic approach is used to model the current situation on the labor market and predict the prospects for the functioning of the team through the implementation of various marketing solutions (Kopylova, 2017; Platoshina, 2016; Kretova, Mitina, 2017). As part of the marketing approach, we focus on SNW and SWOT tools that are focused on identifying factors and threats, as well as recruitment and selection processes.

\section{RESULTS}

We are interested in cognitive modeling in so far as its application determines the growth of efficiency of management decisions for the enterprise as a whole and in the field of personnel marketing, in particular. There is no universal algorithm for developing solutions. The mentioned methodological approaches, continuing and developing each other, have a greater effect when they are applied together in an organic unity. The elements of personnel marketing technology are: selection, adaptation, regulation, evaluation and certification, training, rotation, motivation, staff release, budgeting and personal plans of personnel, and we use cognitive modeling for transparency of the personnel marketing technologies used (Figure 2).

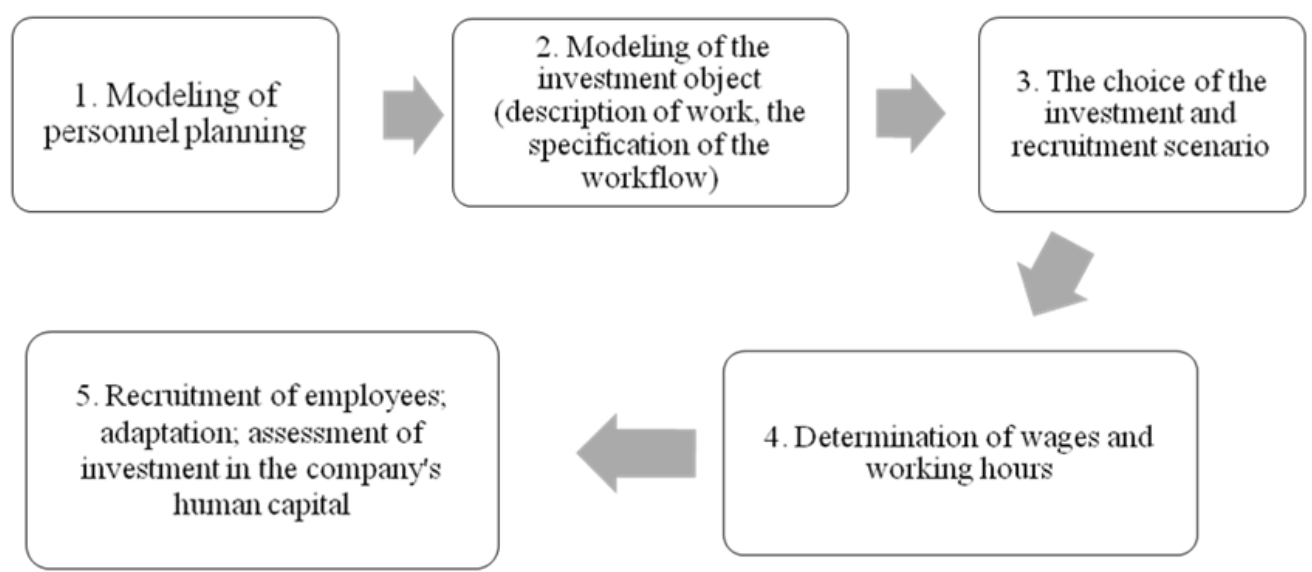

Figure 2. Cognitive map of the company's investment program

We believe that this program should be implemented by line managers, HR managers and top management of the company. The division of functions by stages and content should differ depending on the type of enterprise, since the sources of recruitment are diversified. Labor evaluation, training, training 
and retraining should also be included in the personnel marketing system (Solovyov, 2015; Vanyan and Demyanchenko, 2016).

One of the manifestations of the communication function of personnel marketing is the implementation of links within the enterprise. Their task is to highlight the informal elements of relations in the enterprise. The company's staff develops a positive image of the employer. It can affect the consolidation of human resources within the enterprise, work on its improvement outside the enterprise, since the staff is considered as a carrier of goodwill (Rozhkova, 2018; Semina, 2017; Kropivnitsky, 2011).

Sources of personnel information are: relevant legal acts; Analytics of Rossstat; employment and employment services; Internet; advertising within the industry, region, macro region; interviews with candidates; information of subjects of the educational services market; conversations with representatives of the business community; surveys of their own staff. We agree with those authors who believe that the information function of personnel marketing involves studying the requirements that candidates for vacant positions have for their profession, position and workplace (Sergienko, Pisareva, 2018). These include: knowledge, skills, experience, personal competence of the applicant, motivation, sphere of interests, values, learning ability, stress tolerance, etc. Implementation of the information function of personnel marketing is impossible without research of internal and external labor markets, personnel structure, their motivational attitudes, business processes, corporate culture, etc.

An important stage is to study the image of the employer from the point of view of competitors. The information function of personnel marketing allows you to identify areas where problems with personnel may occur and take timely preventive measures. Marketing information system in personnel management is a system of information exchange that allows personnel marketing specialists to analyze, plan and implement marketing activities. The basis of the system of marketing information on personnel is the sources of this information, namely:

-educational programs and graduation plans of students from educational institutions;

-training programs for additional training in commercial training centers and for retraining and advanced training courses at the labor exchange;

- analytical materials of state bodies on labor and employment;

- information messages from employment services, etc (Gorbunova and Khmeleva, 2017; Temirtayeva, 2020; Proskuryakov, 2016).

Monitoring the requirements for jobs forms a system of requirements that the company makes to the personnel applying for vacant jobs. Requirements for personnel are expressed in groups of parameters and are determined by the nature of work. Level of education; necessary knowledge; practical skills in a particular field of professional activity; experience in certain positions; skills of cooperation and mutual assistance: these characteristics of the candidate reflect their abilities. Personal qualities, stress resistance; ability to concentrate: these characteristics of the candidate reflect their properties (Platoshina, 2016; Kropivnitsky, 2011; Mishchenko, 2020). The desire for self-expression and self-realization; the ability to learn; interest in work, clarity of understanding of the trajectory of their own career: these characteristics of the candidate reflect their motivational attitudes.

Requirements for the position are reflected in the company's regulatory documents:

- job description, including the organizational status of the position, professional duties, rights, relationships of the position or workplace; 
- job specifications that reflect the personal characteristics required for the job;

- a qualification card that includes information about General and special education, work skills;

- a map of competencies that describes personal characteristics, abilities to perform official functions, and the type of behavior of employees.

The methods of segmentation of the labor market include factor and cluster estimates. Factor estimation is based on criteria for forming target groups, which include geographical, demographic, economic, psychographic, and behavioral criteria (Abdurakhmanov, 2019; Kublin et al., 2019; Stepchenko, Khodyreva, 2014; Kropivnitsky, 2011). The cluster assessment is based on the characteristics of carriers by age, gender, marital status, level of education, etc. Effective segmentation provides the definition of the subject of communication between the employer and the labor market through the formalization and application of transparent algorithms for covering personnel needs. At the same time, the main thing in the development of human resources is to achieve strategically set goals by implementing innovative HR technologies. We update the solution of personnel marketing tasks based on innovative HR technologies using another cognitive model. Here marketing communications aimed at: analyzing the labor market and developing specialized recommendations; calculating the cost of recruitment and selection of personnel; developing a program for attracting new employees and improving working conditions; encouraging employees for quality work; organization of training and team building for the team; interaction with the media and informal leaders, etc.

\section{DISCUSSION}

We agree with Ivanov and Petrov that the key conditions for the development of HR marketing should include (Figure 3).

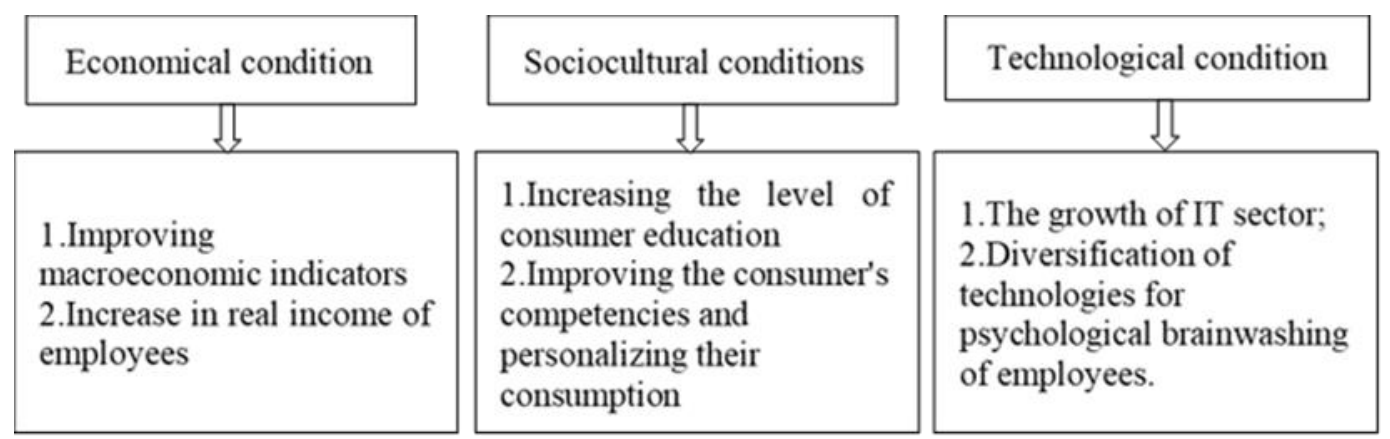

Figure 3. Conditions for the development of personnel marketing

We believe that cognitive modeling activates the imaginative thinking of employees and thus contributes to the emergence of new ideas. It expands and clarifies the goals set for the staff, contributes to the identification of tasks to be solved and projects to be implemented. Today, cognitive computer modeling is widely used in the field of marketing cognitive maps-a model presented in the form of a graph that allows you to describe the subjective perception of an employee or team of a particular problem (Rozhkova and Chashchin 2018; Sardak, 2012). The implementation of market research of the labor market in the process of forming the company's personnel allows you to timely meet the needs of the company in personnel, increase productivity and ensure its goodwill in the labor market.

We share the scientific views of Ivanov and Petrov, according to which it is legitimate to distinguish the following components of HR marketing: 
- development of quality requirements for personnel;

- determining the quantitative and qualitative need for personnel;

- calculation of costs for selection, selection, hiring and use of personnel;

- choice of ways to cover the need for personnel;

- personnel assessment;

- audit of the efficiency of the distribution staff.

The final set of problems of personnel management is related to the sources of covering the need for personnel. We will refer to external sources of covering the needs of professional infrastructure (universities, technical schools, schools, labor exchanges, outsourcing, etc.). Internal sources will include elements of self-sufficiency of the company's personnel needs (rotation, Institute of curatorship, Institute of mentoring, etc.).

\section{CONCLUSION}

So, the level of development of personnel marketing allows you to clearly respond to changes in the internal labor market and implement an active and competitive marketing strategy. Company managers, operating in the space of relationship marketing, should remember that it is necessary to create comfortable working conditions, because the prospects for business growth often depend on the ability of employees to adapt to unpredictable economic processes, which actualizes the tools of internal marketing and interactive marketing.

\section{REFERENCES}

Abdurakhmanov, A.A. (2019). Influence of integrated marketing communications (IMC) on consumer behavior. Economics: yesterday, today, tomorrow, 9(3-1), 529-535.

Gorbunova, O.A, Khmeleva, K.E. (2017). Strategic analysis of personnel in the system of internal marketing. Bulletin of the Samara Polytechnic Institute, 2, 76-86.

Kopylova, Yu.V. (2017) Marketing of personnel in human resource management. European Social Science Journal, 7, 89-94.

Kretova, N.N., Mitina, N.N. (2017). Features of personnel marketing implementation in modern Russian conditions. Bulletin of Volgograd state University. Series 3: Economics. Ecology, 19(2(39)), 88-96.

Kropivnitsky, Yu.G. (2011). Consensual approach to the definition of "marketing personnel". Bulletin of Khmelnytskyi national University, 1, 150-153.

Kublin, I.M., Plekhanov, S.V., Ryabchenko, A., Ludovic, E.E. (2019). Innovative tactical marketing approaches: features, accounting and analysis of efficiency. Economics of sustainable development, 3(39), 129-133.

Mishchenko, T.L. (2020) Marketing in the organization's personnel management. Eurasian scientific community, 1-3(59), 216-220. 
Platoshina, G.G. (2016). Strategic marketing of higher education. Economics of education, 4, 14-20.

Proskuryakov, V.V. (2016). Development of marketing strategies for competitive enterprise development. Science and business: ways of development, 4, 118-123.

Rozhkova, M.V. (2018). Marketing of personnel in the reporting system on the labor market. Economics: yesterday, today, head, 8(11a), 166-172.

Rozhkova, M.V., Chashchin, V.V. (2018). Trust in marketing relationship: theoretical and practical aspects. Economics: yesterday, head, 8(11a), 114-122.

Sardak, O.V. (2012). Integrating entrepreneurship to entrepreneurship to HR-marketing of entrepreneurship. Visnic Nachalovskoe University of water and nature domination. Series "Economy", 4(52), 202-209.

Semina, N.A. (2017). Theoretical bases of personnel marketing and its effectiveness. Agro-Food policy of Russia, 8(68), 98-101.

Sergienko, E.S., Pisareva, E.V. (2018). Marketing approach to personnel management: problems and solutions. Economics and management: scientific and practical journal, 4(142), 127-131.

Solovyov, B.A. (2015). Marketing research-the basis of the University's strategy. Bulletin of the Plekhanov Russian Academy of Economics, 6, 3-9.

Stepchenko, T.S., Khodyreva, T.V. (2014). Specifics and features of marketing communications in the field of education. Economics and entrepreneurship, 11-2(52), 414-419.

Temirtayeva, A.T. (2020). Marketing technologies in the personnel selection system. Scientific and practical research, 1-3(24), 249-252.

Vanyan, M.N., Demyanchenko, N.V. (2016). Personnel Involvement as an effect of marketing activities in the attitude of employees of the enterprise. Economics of sustainable development, 1(25), 71-79. 